\title{
Belgeo
}

Revue belge de géographie

\section{Landscape research in Greece: an overview}

Aperçu de la recherche sur les paysages en Grèce

\section{Theano S. Terkenli}

\section{(2) OpenEdition}

\section{Journals}

\section{Electronic version}

URL: http://journals.openedition.org/belgeo/13713

DOI: 10.4000/belgeo.13713

ISSN: 2294-9135

\section{Publisher:}

National Committee of Geography of Belgium, Société Royale Belge de Géographie

\section{Printed version}

Date of publication: 30 September 2004

Number of pages: $277-288$

ISSN: 1377-2368

\section{Electronic reference}

Theano S. Terkenli, «Landscape research in Greece: an overview », Belgeo [Online], 2-3 | 2004, Online since 14 September 2013, connection on 08 July 2020. URL : http://journals.openedition.org/belgeo/ 13713 ; DOl : https://doi.org/10.4000/belgeo.13713

This text was automatically generated on 8 July 2020 .

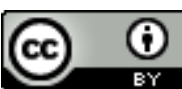

Belgeo est mis à disposition selon les termes de la licence Creative Commons Attribution 4.0 International. 


\title{
Landscape research in Greece: an overview
}

\author{
Aperçu de la recherche sur les paysages en Grèce
}

Theano S. Terkenli

\section{AUTHOR'S NOTE}

Though an effort has been made to make this list of references as inclusive as possible, due to the breadth and multidisciplinarity of the field as well as of the indirectness to the subject matter of a lot of work that touches on the Greek landscape, this list remains largely indicative, simply aiming to be as representative as possible of the variety and types of relevant current publications. Unpublished research projects/ studies reports or very short articles (less than 3 p.) have not been included here.

For their generous cooperation and valuable input in the expert survey conducted for the purposes of this article, the author wishes to thank Maria Ananiadou-Tzemopoulou, Theodosia Anthopoulou, Harry Coccossis, Panagiotis Doukellis, Ekaterini Goltsiou, Athanasios Kizos, Ilias Lolidis, Harry Papaioannou, Maria Sioliou-Kaloudopoulou, Andreas Troumbis, and Androniki Tsouchlaraki, as well as Sotirios Koukoulas for his kind assistance and expertise in the making of the map. Any problems or omissions from this work, however, remain solely the author's responsibility and are entirely unintentional.

\section{Introduction}

1 Processes of establishment of landscape science, research and practice as such have been slowly gaining ground in Greece in very recent years. Specifically, in the 1990s, landscape science underwent a shift from the fragmentary, peripheral and haphazard preoccupation of the so-called design sciences (architecture, landscape architecture, urban and regional planning) with practical landscape issues as they developed out of related design and planning initiatives and interventions in space to a more concerted, 
focused and systematic landscape approach by several more disciplines and practitioners. This has, so far at least, remained mainly a qualitative shift characterized by its very limited extent and impact on actual landscape problems and issues in Greece and one that is largely suffering from disciplinary limits and from the lack of communication and cooperation between academics, practitioners and administrators as well as from effective application in landscape policy. In fact, the Greek landscape, taken for granted till the end of the 1970s, was first acknowledged through interconnections emerging at the time between agricultural modernization and the rural landscape and between nature and human society. With pressure mounting from E.U. and OECD initiatives onto landscape research, planning and policy, Greece is currently finding itself in a position of having to struggle to meet its own landscape problems and challenges at a fast pace and to develop its own landscape agenda for the future.

\section{Fields of landscape research and disciplines involved}

2 The disciplines of geography, landscape architecture, architecture, urban (and minimally regional) planning, rural studies, history, landscape ecology, forestry and environmental studies are those mainly involved at present in active landscape research and in the application of landscape science in Greece. The discipline of geography, newly emergent in Greece since 1994, seems to be quite active in landscape research undertaken at the moment. The study of landscapes has been one of the longest traditions in human geography. Implicit in this tradition is an essentially cultural and synthetic definition of landscape as a real, perceived or imaginary site that supports unquestioned assumptions about the spatial organization of society and culture through a naturalization of particular readings from particular positions. The status of current landscape research in Greece will be explored in the remainder of this article on the basis of this broader definition of landscape as adopted by the discipline of geography.

3 The main domain of landscape science in which the discipline of geography in Greece is actively involved is fundamental research in human/ social and physical aspects of landscape theory, analysis and planning. Such work has been conducted in multidisciplinary teams (Department of Geography, Harokopio University 2001) but more often by individual academics (i.e. Hadjimichalis, Terkenli) and students at various levels of their academic studies - though only one course directly relevant to the cultural landscape is offered as an elective (Department of Geography, University of the Aegean). In fact, due to Greek geography's long-standing links to the design sciences, it seems that, besides landscape architecture, geography is probably the main discipline in Greece where inter-disciplinary landscape research involving more than two scientific fields at a time is currently undertaken.

4 The absence of landscape, not only as an object of research and as a historical resource but also in terms of practical spatial interventions, is similarly ubiquitous in the discipline of history. Not only is it absent even in its most ground-breaking and sophisticated recent scientific endeavors, but also there seems to be confusion between the historicity of landscape and historical geography. The concept and study of landscape in the discipline of history in Greece has been very recently introduced by archeologists through the adoption of principles and methodologies of the New 
Archeology and the emphasis has been on moving from research on archeological locations to research on the network of archeological locations in a broader geographical region. In sum, the landscape concept and question has but just become a point of interest, either explicitly or implicitly, in archeological research, if only through mostly parochial cartographic practices and through planning and implementation of archeological protection zones. With one significant exception (the work of P. Doukellis), in the discipline of history the landscape has not achieved similar significance, if only in the field of archeo-history, which essentially coincides with the perspective of the historical geographical approach to space, rather than of landscape history per se.

5 Also in the field of landscape ecology, very few specimens of concerted work exist in Greek academia and the professional world: applications are found mainly in natural hazards research, planning of protected areas and minimally in physical land use planning and evaluation. Academicians tend to abuse the landscape concept in ecological usage, equating it with ecosystem and ecotope, while rural studies professionals confuse landscape ecology with landscape architecture. Similarly, agricultural and forestry schools confuse landscape study with landscape architecture. There is a substantial amount of research on the natural landscape and on methods and techniques of landscape analysis, however, conducted at university laboratories (National Technical University of Athens, Aristotelian University of Thessaloniki) and minimal, fragmentary practical application of such methods and techniques mainly in environmental impact studies (forest engineering, landscape architecture or architectural offices and firms). As far as the natural or forest landscape is concerned, with few exceptions (i.e. Eleftheriadis, Kassios), research in related academic fields in Greece is in its infancy and applications extend only as far as studies revolving around recreation planning and design or landscape reclamation.

6 With regard to the rural landscape in particular, two conflictual positions prevail in Greece today: that of the landscape as an indispensable part of Greek (agri-)cultural heritage demanding the protection (even if in the form of museums) of its most significant characteristics and that of the landscape as a rural development arena, regardless of the type of human intervention. In rural studies, rural geography, rural sociology and local/rural development, the landscape is conceptualized as a productive resource, either in primary economic production or in tourism, and as a vital living space for its rural inhabitants. Here too, landscape science is still in its infancy, still grappling with issues of landscape conceptualization. There has been little concerted effort in Greece by either academics (i.e. Kizos) or professionals to develop a rural landscape science in terms of either primary research or practical intervention in rural space. Academic interest in the rural landscape has produced some very sporadic research on either particular agricultural landscape features (such as island terraces) or studies at a more general level. Besides older studies of the Greek landscape by French geographers, there have been some more recent studies on innovative action in rural environment protection, promotion and education, as well as on agricultural landscape modernization. Thus, both at a research level and in practice, any agricultural landscape measures or interventions stem from E.U. or state environmental projects, such as regional development projects (i.e. the protection of vineyard landscapes in Santorini) and the implementation of Common Agricultural Policy (C.A.P). Regulations in the context of agro-environmental measures. C.A.P. has 
been the main driving behind most change in rural space- change that has proven to be detrimental to the Greek landscape.

7 From a research and an academic viewpoint, university departments in geography, architecture, agriculture, forestry and engineering university departments around the country offer one-semester courses on the landscape in their study programs and are variously involved in landscape research. With regard to landscape architecture, though coming from different academic backgrounds, the work of AnaniadouTzimopoulou and Tsalikidis stands out. From an applied viewpoint, the discipline of landscape architecture has been most active in landscape science through its practical applications (landscape design). In this context, professional landscape architects and secondarily geographers, architects, forest engineers, and urban and regional planners, have been conducting research on landscape analysis/ methodology, landscape visitor behaviour, design theory and landscape reclamation. In practice, professionals in landscape architecture, architecture, and rural studies are those who have mostly contributed to the field. With regard to landscape design, academic departments of architecture, agriculture and forestry represent the only higher education settings where the subject is taught; certain technical institutions now also train landscape technicians and a few doctoral dissertations in academic departments around the country negotiate various aspects of the Greek landscape. Very recently (2002), efforts to develop a landscape science degree at a Greek higher institution have succeeded in the creation of the first graduate program in landscape architecture by the departments of Agriculture and Architecture at the Aristotelian University of Thessaloniki.

8 Finally, a similar situation exists in the fields of planning and architecture, where applied/ practical interventions relatively exceed fundamental/ theoretical contributions to landscape science. With the exception of a significant body of work on the built landscape (i.e. Stefanou, Ananiadou-Tzimopoulou), landscape does not explicitly constitute an important factor in the design sciences in Greece, either at an academic or at a practical level, except very sporadically and partially. While, as a rule, landscape science is in its infancy in all disciplines and fields of practice pertaining to the landscape in Greece, in each one of the fields of landscape research or practice examined here the work of one or two individuals stands out as an exception to this rule. The field of planning in Greece is tangentially occupied with the landscape only insofar as space aesthetics and land use are concerned. At a theoretical and research level, most published work refers to the built environment and to the protection of traditional contexts and archeological settlements. At a practical level, involvement with the landscape is focused in matters of urban planning and architecture pertaining to space regulation and intervention, but, on the whole, judged as poor and unsystematic. In specific, practical intervention in the urban landscape occurs mainly through zones of development control, such as in building volume and height restrictions (in protected landscapes, for example, around the Acropolis of Athens and the town of Molyvos on the island of Lesvos), implemented by urban planning and architectural control committees and urban planning offices. 


\section{The current state of the Greek landscape: landscape types, values, potentials and threats}

9 Throughout Greek history, continuous and unchecked human intervention has been irreparably degrading the Greek landscape; indeed the destruction of the Greek natural landscape originates in pre-historic times, around 1,000 BC. Prehistoric landscapes, however, became physically and geomorphologically established earlier on, with the consolidation of the Aegean coastline about 9,000 years ago, when the Aegean Sea, after millennia of sea-level change assumed its present position. From this point on, a very basic distinction emerges and becomes established through time in Greek landscape typology: island landscapes, coastal landscapes and inland landscapes. At a high level of generalization, the first major landscape changes seem to have occurred in the third millennium B.C. (era of the urban revolution) with the development of the first cities out of long-standing processes of cultural evolution introduced and accelerated through new technologies such as metallurgy, which facilitated the extraction of natural resources and the growth of commerce.

Both from a physical geographical and from a human geographical perspective, the three types/ regions of Greek landscapes represent three different, albeit highly variable and historically changing, geographical entities. On the basis of their cultural, natural and symbolic differentiation through time, these three types (island, coastal and inland landscapes) constitute the elementary framework of historical landscape development presented in this article (Table 1), as well as the basis for the landscape map (Figure 1). In 2001, 39\% of the total Greek population lived in coastal areas constituting $28 \%$ of the total land of Greece and exhibiting dynamic demographic growth (National Statistical Service of Greece 2001). Coastal landscapes (delimited for our purposes to the zone of $10 \mathrm{~km}$ from the coastline) are further distinguished into urban and non-urban landscapes, whereas inland landscapes (to the interior of the coastal zone of $10 \mathrm{~km}$ ) are further divided by the contour line of $200 \mathrm{~m}$. elevation into plain/semi-plain and semi-mountainous/ mountainous landscapes (Figure 1). Both the table and the map are characterized by a high degree of generalization and simplification in matters pertaining to the organization of space, time and cultural differentiation; by exposing more challenges and creating more contradictions than suggesting answers to the landscape question they only take a small step towards inviting more future landscape research. 
Table 1. Historical phases of Greek landscape development.

\section{MAIN LANDSCAPE TYPES}

\begin{tabular}{|c|c|c|c|}
\hline \multirow[t]{2}{*}{ Chronolog } & & \multirow{2}{*}{ COASTAL } & \multirow{2}{*}{ INLAND } \\
\hline & ISLAND & & \\
\hline $\begin{array}{l}3^{\text {rd }} \text { Millenium BC- } \\
5^{\text {th }} \text { century BC }\end{array}$ & \multicolumn{3}{|c|}{$\begin{array}{l}\text { Urban Revolution, establishment of first cities, emergence of great } \\
\text { cultural centers of antiquity, beginning of natural landscape } \\
\text { degradation }\end{array}$} \\
\hline $\begin{array}{l}5^{\text {th }} \text { century BC- } \\
4^{\text {th }} \text { century AD }\end{array}$ & \multicolumn{3}{|c|}{$\begin{array}{l}\text { Rise and fall of ancient Greek city-states, accelerated destruction of } \\
\text { natural landscape, idealized arcadian landscape of antiquity }\end{array}$} \\
\hline $\begin{array}{l}4^{\text {th }} \text { century AD- } \\
14^{\text {th }} / 15^{\text {th }} \text { century AD }\end{array}$ & \multicolumn{3}{|c|}{$\begin{array}{l}\text { Christianity and Middle Ages, consolidation of previous landscape } \\
\text { impacts and characteristics and slow, gradual introduction of } \\
\text { few new ones }\end{array}$} \\
\hline $14^{\text {th }} / 15^{\text {th }}$ century AD- & \multicolumn{3}{|c|}{ Occupation of Greece by Ottoman Empire } \\
\hline $1820 s-1830 s$ & $\begin{array}{l}\text { Defensive hilltop } \\
\text { settlements, life of } \\
\text { hardships }\end{array}$ & $\begin{array}{l}\text { Highest impact of } \\
\text { Ottoman occupation, } \\
\text { stagnant societies }\end{array}$ & $\begin{array}{l}\text { Idealized landscape } \\
\text { of the mountains, } \\
\text { freedom, "good life" }\end{array}$ \\
\hline $1820 s-1830 s-$ & \multicolumn{3}{|c|}{ Foundations of the Modern Greek State $-20^{\text {th }}$ century } \\
\hline $1950 s-1960 s$ & $\begin{array}{l}\text { Poverty, isolation, } \\
\text { abandonment, } \\
\text { desertion }\end{array}$ & $\begin{array}{l}\text { Slow, steady rates } \\
\text { of growth, new cultural } \\
\text { identity and landscape }\end{array}$ & $\begin{array}{l}\text { Gradual liberation of } \\
\text { all Greece, cycles of } \\
\text { growth and decline }\end{array}$ \\
\hline $1950 s-1960 s-$ & \multicolumn{3}{|c|}{ «Industrial Revolution» and urban development and growth } \\
\hline Today & $\begin{array}{l}\text { Tourism, growth, } \\
\text { development, island } \\
\text { landscape idealization }\end{array}$ & $\begin{array}{l}\text { Unparalleled urban } \\
\text { growth/ development, } \\
\text { landscape destruction }\end{array}$ & $\begin{array}{l}\text { Desertion, isolation, } \\
\text { poverty, loss of social } \\
\text { dimension of rural } \\
\text { landscapes }\end{array}$ \\
\hline
\end{tabular}

Figure 1. Greek landscape types: a schematic map.

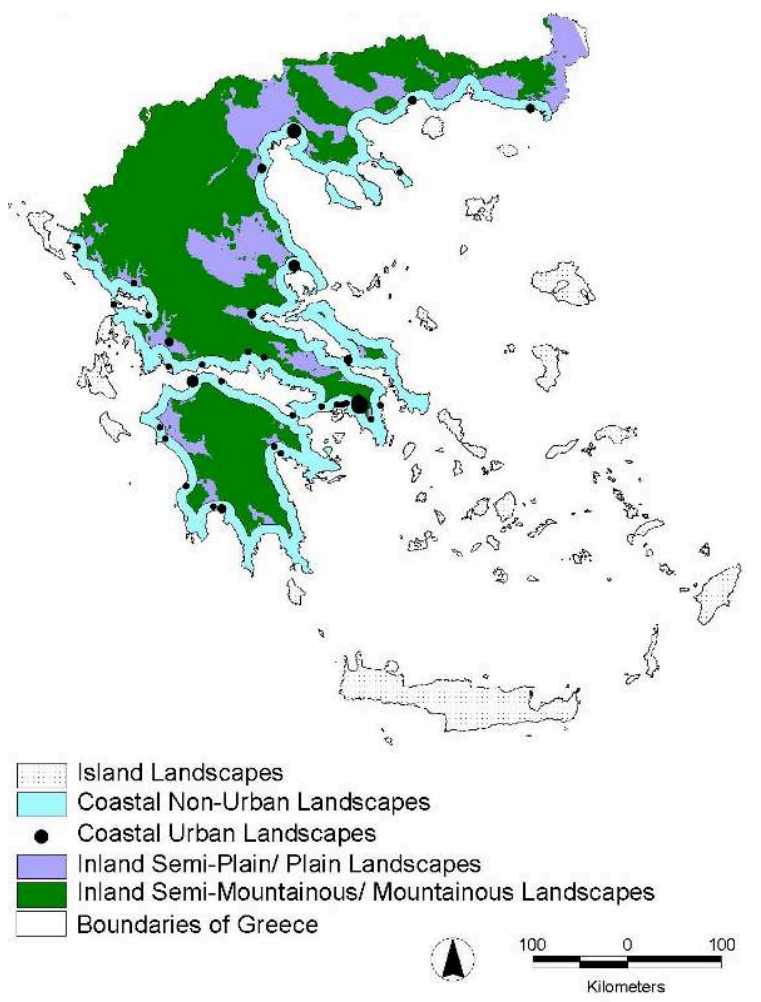

11 The main values of the contemporary Greek landscape may be grouped into three categories: uniqueness, diversity and richness. Landscape uniqueness (identity) refers 
to the distinctive geographical expressions of its ecological, aesthetic, cultural and historical values. Its enormous diversity, in terms of the natural environment and agroecosystems, is related to its geomorphology, the micro-rural structures of Greek agriculture and the variability of Mediterranean agricultural ecosystems etc. It is equally related to the depth of the landscapes cultural heritage as imprinted on the built environment (bridges, fences, terraces, fountains, folk architecture etc.), all exhibiting enormous richness in physical and cultural landscape forms, functions and symbolisms. Through the centuries, the Greek landscape has been heavily invested with spirituality and other metaphysical and ethical qualities, though its highest value remains that of a rich context of human life. One of its basic values is indeed its depth of its historicity, as evidenced from a variety of real, imaginary and mythological data, threatened by factors related to multiple contemporary facets of «development». Moreover, it is a context that carries the potential of being developed for pedagogical purposes, in order to foster a natural (versus an ecological) conscience. Finally, it represents a very significant asset in tourism promotion and more general place promotion, aiming at local development, through population retention and increased employment opportunities (the case of the Cyclades and Northern Crete).

The dangers and problems that the Greek landscape faces at present are manifold: land subdivision, land use change and lack of comprehensive rational planning, partial documentation and historical landscapes restoration, unchecked urban development and the banalization of landscape, intensification of agriculture and homogenization of agricultural landscapes, loss or degradation of its natural, aesthetic or cultural character (i.e. through soil erosion, collapse of old structures, interventions incongruous to local landscape identity etc.), desertion of mountain and remote rural landscapes through abandonment of traditional rural activities, unequal development or geographical exclusion/ discrimination, lack of protection measures from illegal interventions, fires, floods, etc. What the contemporary Greek society is witnessing is the selling-off of the Greek landscape or its overwhelming dependence on state or individual economic or political interests. Local interests and input are normally ignored or essentially non-existent. Finally, the Greek landscape is plagued by yet another ghost: the precedence of the State Archaeological Service in legal matters and decision-making concerning landscape planning, policy and management as well as determining land use for industrial, agricultural, or other general development purposes.

13 Although almost every practical intervention in space in one way or another pertains to or affects the landscape, the institutional context for the Greek landscape in terms of a landscape science is in effect non-existent in Greek legislature. Its proper existence is legally acknowledged in the environmental context, where it is defined as «any dynamic entity of biotic and a-biotic environmental factors and elements that either separately or interactively compose a visual experience in a given space» (Issue of Government Gazette 160/16-10-1986, 3258). It appears in various environmental laws, master plans and regulatory statutes, in effect in statutes concerning the protection of archeological spaces, as well as in legislature on traditional settlements, aesthetic forests and national parks and is implicitly or explicitly dealt with in environmental legislature as «areas of high biological, ecological, aesthetic or geomorphologic value» (Issue of Government Gazette 160/16-10-1986, 3257). Two categories of protected natural landscapes have so far been established in Greece, «aesthetic forests» and «landscapes of natural beauty»; their existence, nonetheless, plays a minimal role in 
forestry planning. Besides international organizations active in Greece (E.U, ICOMOS, W.W.F. etc), most significant factors in landscape policy-making and management in essence remain the Archeological Service of Greece, the Ministry of Culture and the Ministry of Environment, Planning and Public Works, NGOs, local governmental or private factors (Egnatia Odos S.A., Public Electricity Corporation) and some civic societies.

\section{Concluding remarks}

Though academic interest in the field has recently grown, so far progress has been minimal, fragmented and slow, necessitating much further engagement in landscape theory, methodology and development of techniques, as well as practical application and implementation of theoretical and research findings. From a theoretical perspective, the Greek landscape is at a pre-paradigm stage. A case in point is the total lack of Greek landscape maps, a task now in its infancy. At a practical level, applied intervention in the urban/ built Greek landscape has predominantly been a longstanding tradition of the design sciences. Generally speaking, systematic physical planning interventions have been largely restricted to metropolitan and urbanized areas, whereas mobilization in matters pertaining to the agricultural landscape in Greece has only been very recently instigated through European Union legislation and subsidized interventions (C.A.P.) that enforce the protection and preservation of the rural landscape.

In conclusion, traditional patterns of small-scale rural activities in Greece have historically retained observed distributions of human geographical density in landscape mosaics of high cultural and ecological value. These have produced a high degree of ecological and cultural diversity in highly heterogeneous but cohesive landscape contexts. Culturally, such landscapes in Greece are the outcome of historical processes of land division as imposed by the church or the state, but also by individual or community intervention in the function of certain physiographic parameters (i.e. through terracing) and the striving for subsistence in restricted and marginal lands. In these cases, the basic dangers today lie in the changing scales of landscape structure and function, urbanization, agricultural intensification or alternately landscape desertion. As contemporary rural spaces urbanize at a fast pace, landscape analysis and management are becoming increasingly pressing in Greece through concern for the environment more generally (agro-ecosystem degradation, housing construction and urban expansion). They are also becoming increasingly imperative through the growth of ecotourism and agrotourism, through a re-discovery of the Greek cultural heritage and through tendencies that are just emerging among urbanites of a return to nature and to rural and environmental values and cultural roots. 


\section{BIBLIOGRAPHY}

ANAGNOSTOPOULOS G. (ed.) (1998), Proceedings of the International Federation of Landscape Architects Congress on Art and Landscape, Athens, Panayotis and Effie Michelis Foundation.

ANANIADOU-TZIMOPOULOU M. (1979), «Landscape and Spatial Design, Theoretical Approach and Practical Application of Landscape Study» (in Greek), Technica Chronika, vol. 2.

ANANIADOU-TZIMOPOULOU M. (1982), «Transformation of Greek River Landscapes Through the Development of Human Settlement», IFLA Yearbook Activities, Athens, IFLA.

ANANIADOU-TZIMOPOULOU M. (1982), Landscape Analysis in Planning: Contribution to Landscape Architecture Research (in Greek), Ph.D. Dissertation, Thessaloniki, Scientific Annals of the Polytechnic School; Aristotelian University of Thessaloniki.

ANANIADOU-TZIMOPOULOU M. (1985), «Landscape Analysis in Studying Protected Areas; a Socioecological and Perceptual Approach», Park News, 21 (2).

ANANIADOU-TZIMOPOULOU M. (1988), «Lecture du paysage et création - Le parc de la Paix à Thessaloniki», IFLA Yearbook, Athens, IFLA.

ANANIADOU-TZIMOPOULOU M. (1989), «Landscape Architectural Research on River Axios» (in Greek), Technica Chronika 9 (4).

ANANIADOU-TZIMOPOULOU M. and FATOUROS D. A. (1990), «The Ayia Varvara Project: A Case of Urban Landscape Design», Landscape and Urban Planning, 19.

ANANIADOU-TZIMOPOULOU M. (1992), Landscape Architecture, Urban Design: Critique and Theory, Contemporary Tendencies in Landscape Design (in Greek), Thessaloniki, Ziti Publications.

ANANIADOU-TZIMOPOULOU M. (1992), «Landscape and Urban Open Space Design in Thessaloniki» (in Greek), Technika Chronika 4.

ANANIADOU-TZIMOPOULOU M. (ed.) (1994), Landscape Architectural Urban Open Space Design, Aristotelian University of Thessaloniki, School of Architecture Symposium Proceedings, Thessaloniki 1993, Ziti Publications.

ANANIADOU-TZIMOPOULOU M. (1994), «Landscape Architecture of Open Urban Spaces» (in Greek), Annals of the Congress The Declaration of Thessaloniki, Thessaloniki.

ANANIADOU-TZIMOPOULOU M. (1995), «Open Urban Spaces and their Design» (in Greek), Geotechnical Chamber of Commerce Publications, Green and Local Government, Kavala.

ANANIADOU-TZIMOPOUOU M. (1998), «Contemporary Tendencies in Landscape Architecture and Urban Design» (in Greek), Interdisciplinary Symposium «Landscape Architecture and Urban Environment» Proceedings, Thessaloniki, Aristotelian University of the Thessaloniki, Department of Agriculture.

ANANIADOU-TZIMOPOULOU M. (1998), «Landscape Design Projects, Works of Art and Culture», IFLA Central Region Symposium «Art and Landscape» Proceedings, Athens, IFLA.

ANANIADOU-TZIMOPOULOU M. (1999), «Landscape Architecture. Current Design Tendencies and Cultural Works» (in Greek), Scientific Congress «Landscape Architecture» Proceedings, Athens, National Technical University of Athens.

ANANIADOU-TZIMOPOULOU M. (1999), «The Legacy of Greece in Landscape Design» and «Pascha Gardens», Topos/ the State of European Landscape Architecture, 27. 
ANTHOPOULOU T., DUQUENNE M.-N. \& GOUSSIOS D. (2000), «Agricultures familiales et développement rural en Méditerranée. Le cas grec» (in French), Agricultures familiales et développement rural en Méditerranée, pp. 260-319, Paris, Karthala-CIHEAM.

ANTHOPOULOU T. (2001), «Geographical Approach to the Countryside: Spatial Differentiation and Reconstitution» (in Greek), in ANTHOPOULOU T. \& MOISIDES A. (eds.), From Rural Space to the Countryside: Restructuring and Current Conditions of the Rural World in Greece, pp. 103-147, Athens, Panteion University and Gutenberg.

ARAVANTINOS A. \& KOSMAKI P. (1988), Open Spaces in the City (in Greek), Athens, Symeon Publications.

DIMOPOULOU E. (2002), Patrimoine insulaire et représentations locales: le cas du paysage rural dans l'Ile de Céphalonie (in French), DEA en Géographie, Montpellier III, Université Paul Valéry.

DOUKELLIS P. (1998), «Mentalities, Ideologies and Modern Greek Landscape Management», in UNWINT. (ed.), A European Geography, pp. 78-79, London, Longman.

DRAIN M. (1998), «Unité et diversité des paysages méditerranéens» (in French), Le Paysage entre Culture and Nature, REM No 183, Montpellier, ed, pp. 219-233, Centre Régional de la Productivité et des Etudes Economiques.

ELEFTHERIADIS N., TSALIKIDIS I. \& MANOS B. (1990), «Coastal Preference Evaluation: A Comparison Among Tourists in Greece», Environmental Management, Vol. 14, No. 4, pp. 475-487, Springer-Verlag Editions, N.Y.Inc.

ELEFTHERIADIS N. \& TSALIKIDIS I. A. (1990), «Coastal Pine Forest Landscapes: modeling Scenic Beauty for Forest Management», Journal of Environmental Management, Vol. 30, pp. 47-62.

ELEFTHERIADIS N. \& TSALIKIDIS I. A. (1993), «Tourism in the Coastal Pine Forest Zone», Proc. European Union for Coastal Conservation Congress, Mara thon, April 1993.

ELEFTHERIADIS N. (1996), «Aesthetic Deterioration of Peri-Urban Landscapes: The Case of the Quarries of Drama» (in Greek), Environmental Problems of the Prefecture of Drama, Technical Chamber of Greece Publications.

GEORGAKOPOULOU-VOYIATZI C., METAXAS D., NAKOU O. \& TSALIKIDIS I. A. (2000), «Evaluation of Indigenous Ornamental Trees and Bushes With Regard to their Aesthetic Value and Adaptation to the Urban Landscape» (in Greek), Annals of the Department of Agriculture of the Aristotelian University of Thessaloniki, No 32.

GUIDE TO LANDSCAPE RESTORATION DESIGN (1997), Egnatia Odos (in Greek).

HADJIMICHALIS C., HASTAOGROU V., PAPAMICHOS N., PATRIKIOS G., PAVLOPOULOS K. \& SKORDILI S. (2001), Artemis: Identification and Evaluation of the Mediterranean Landscape, Athens, Harokopio University.

HATZISTATHIS A. \& ISPIKOUDIS I. (1995), Nature Protection and Landscape Architecture (in Greek), Thessaloniki, Giachoudi-Giapouli Publications.

KANTARTZIS N. A., ECONOMOU A. S. \& TSALIKIDIS I. A. (1986), The Significance of Flowering of Ornamental Bushes and Trees in Landscape Architecture (in Greek), Thessaloniki.

KASSIMIS CH. \& LOULOUDIS L. (eds.) (1999), Countryside: Greek Agricultural Society at the End of the Twentieth Century (in Greek), Athens, National Center for Social Research, Plethron Publications.

KASSIOS K. (1989), Landscape Analysis and Evaluation; Attic Landscape and Environment (in Greek), pp. 90-101, Athens, Kapon Publications. 
KIZOS T. (2002), The Dynamics of Landscape: Estimating Spatial Impacts of CAP Policies in the Countryside of the Aegean Islands (in Greek), Ph.D. Dissertation, Department of Environmental Studies, University of the Aegean, Lesvos, Greece.

KOZIRAKI M., Ch. GEORGAKOPOU LOU-VOYIATZI \& TSALIKIDIS I. A. (2000), «Exploration of the impact of local factors and of flora on the creation and evolution of historical landscapes in archeological settlements of Herakleion Prefecture and development of landscape architecture methods for their restoration» (in Greek), Proceedings of the Greek Society for the Science of Horticulture, No. 9.

LOULOUDIS L. (1992), «Agricultural Modernization and Agricultural Landscape Change» (in Greek), Topos, Vol. 4/92, pp. 135-155, Athens.

MENDONI L. \& MARGARIS N. (1998), Cyclades: Landscape History and Local Histories (in Greek), Athens, Ministry of the Environment, Regional Planning and Public Works and Center for Greek and Roman Antiquities.

MOUTSOPOULOS N. (1969), «The Responsibility of the Architect Towards Landscape Protection», Technika Chronika, pp. 769-772, Athens.

NATIONAL STATISTICAL SERVICE OF GREECE (2001). www.statistics.gr.

PAPADOPOULOU E. (2000), «Environ ment al Impact Assessment Study» (in Greek), Ktirio, vol. 130, pp. 46-54, Thessaloniki.

PARTHENOPOULOS K. (1979), «The Role of Individual and Social Factors in Environmental Assessment» (in Greek), Technika Chronika, pp. 365-383, Athens.

PECHOUX P.-Y. (1989), «Les paysans de la rive orientale du Bas Nestos» (in French), in KAYSER B., PECHOUX P.-Y. \& SIVIGNON M. (eds.), Trois Etudes sur la Grèce rurale, pp. 67-123, Athènes, Centre National de Recherche Sociale.

RACKHAM O. \& J. MOODY (1996), The Making of the Cretan Landscape, Manchester, Manchester University Press.

ROIDIS H. \& TSALIKIDIS I. A. (1988), «Functional and Aesthetic Aspects of the Landsape Development for Tourism in Chalkidiki, Greece», Proceedings of the IFLA Central Region Symposium, Athens, pp. 93-98.

ROZANIS S. (1984), Excerpts from a Landscape, Athens, Hestia.

SAVVIDE K. (1998), «Environmental Management and Ecological Control (EMAS Guidelines)» (in Greek), Technika Chronika, Vol. 6, pp. 7-11, Athens.

SEMAIOFORIDES G. (1989), «The Attic Landscape and Architects 1953-1963», Attic Landscape and Environment, pp. 254-263, Athens, Kapon Publications.

SIVIGNON M. (1975), La Thesssalie: analyse géographique d'une province grecque (in French), Lyon, Institut des Etudes Rhodaniennes.

SIVIGNON M. (1989), «Les Pasteurs du Pinde Septentrional» (in French), in KAYSER B., PECHOUX P.-Y. \& SIVIGNON M (eds.), Trois Etudes sur la Grèce rurale, pp. 125-163, Athènes, Centre National de Recherches Sociales.

SPATHARI E. (1989), «The Harmony of Nature», Attic Landscape and Environment (in Greek), pp. 82-89, Athens, Kapon Publications.

STATHATOS J. (1996), The Invention of Landscape: Greek Landscape and Greek Photography 1870-1995, Thessaloniki, Camera Obscura. 
STEFANOU J. (ed.), (2001), The Physiognomy of a Place: The Character ofr the Greek City in the 21st Century (in Greek), Athens, National Technical University of Athens and Ministry of the Environment, Regional Planning and Public Works.

STEFANOU J. (ed.) (2000), The Physiognomy of the Greek City (in Greek), Athens, National Technical University of Athens and Ministry of the Environment, Regional Planning and Public Works.

STEFANOU J. (2000), «Experimental Iconology: A Tool for Analysis for the Qualitative Improvement and Tourist Development of Places», in BRIASSOULIS H. \& VAN DER STRAATEN J. (eds.), Tourism and the Environment: Regional, Economic, Cultural and Policy Issues, 2nd Edition, pp. 221-228, London, Kluwer Academic Publishers.

STEFANOU J. (2000), «The Contribution of the Analysis of the Image of a Place to the Formulation of Tourism Policy», in BRIASSOULIS H. \& VAN DER STRAATEN J. (eds.), Tourism and the Environment: Regional, Economic, Cultural and Policy Issues, 2nd Edition, pp. 229-238, London, Kluwer Academic Publishers.

TERKENLI T. S. (1996), The Cultural Landscape: Geographical Approaches (in Greek), Athens, Papazissis and University of the Aegean.

TERKENLI T. S. (2000), «Landscapes of Tourism: A Cultural Geographical Perspective», in BRIASSOULIS H. \& VAN DER STRAATEN J. (eds.), Tourism and the Environment: Regional, Economic, Cultural and Policy Issues, 2nd Edition, pp. 179-202, London, Kluwer Academic Publishers.

TERKENLI T. S. (2000), «Cultural Landscape and Urban Fabric: Landscapes of Everyday Life in the Western World» (in Greek), Proceedings of the Congress on Landscape Architecture and Urban Green: Society, Education, Culture, Thessaloniki, Hellenic Society of the Science of Horticulture.

TERKENLI T. S. (2001), «Towards a Theory of the Landscape: The Aegean Landscape as a Cultural Image», Landscape and Urban Planning, Vol. 57, pp. 197-208, Elsevier Publications.

TERKENLI. T. S. (2002), «Landscapes of Tourism: Towards a Global Cultural Economy of Space?», Tourism Geographies, Vol. 4, No 3, Aug 2002, Routledge (forthcoming).

TISSIER J. L. (2002), «Des Paysages Mediterraneens, Une Mer dans ses Paysages» (in French), in BORNE D. \& SHEIBLING J. (eds.), La Méditerranée, pp. 97-121, Paris, Hachette.

TSALIKIDIS I. A. (1981), Landscape Architecture and Environment (in Greek), Thessaloniki, ASE Publications.

TSALIKIDIS I. A. (1986), «Garden Design Styles in Western Europe from the 17th to mid-19th Century» (in Greek), Agrotika Themata, No. 7, pp. 35-44.

TSALIKIDIS I. A. \& ROIDIS H. (1988), «A Critique of Design Guidelines in Public Open Spaces in Thessaloniki, Greece», Proceedings of the IFLA Central Region Symposium, Athens, pp. 169-174.

TSALIKIDIS I. A. (1987), Contemporary Greek Gardens (in Greek), Thessaloniki, Gartagani Publications.

TSALIKIDIS I. A. (1990), «Gardens of Eclectic Villas in Thessaloniki: A Concept of Landscaping in the Southern Balkans in the Late 19th Century», Landscape Journal, Vol. 9, No 1, pp. 28-41.

TSALIKIDIS I. A. (1991), «Outdoor Space Design: Design-Synthesis Process» (in Greek), Ktirio, Vol. 40 , pp. 65-71.

TSALIKIDIS I. A. (1991), «Outdoor Space Design: Basic Principles of Analysis-Study of the Area and of the User» (in Greek), Ktirio, Vol. 40, pp. 32-41. 
TSALIKIDIS I. A. \& KOSMIDOU O. (1993), «Urban Regeneration: Telloglio Foundation Park», Landscape Architecture Europe, Vol. 1, p. 36.

TSALIKIDIS I. A.(1994), Ornamental Plants for Greek Gardens (in Greek), Thessaloniki, Paratiritis Pulblications.

TSALIKIDIS I. A. \& TAMOUTSELI K. (1997), «Landscape Architecture and Environmental Industry» (in Greek), Ktirio, Vol. 41.

TSALIKIDIS I. A. \& TAMOUTSELI K. (1998), «Methodology of Reclamation and Preservation of Historical Gardens: Contribution to the Protection and Conservation of Cultural Heritage» (in Greek), Ktirio, B/ 1998.

TSALIKIDIS I. A. \& TAMOUTSELI K. (1998), «Contemporary Trends in Landscape Architecture of Outdoor Urban Spaces» (in Greek), Proceedings of the Greek Society for the Science of Horticulture.

TSALIKIDIS I. A., VOYIATZI C. \& TAMOUTSELI K. (1999), «The Use of Olive Tree in Ancient and Contemporary Garden Design of the Mediterranean Region», Acta Horticulturae, Vol. 474, pp. 767-770.

Tsouchlaraki A. (1997), Evaluation Methodology of the Visual Value of the Natural Relief (in Greek), Doctoral Dissertation, Athens, National Technical University of Athens.

\section{ABSTRACTS}

Though both academics and practitioners have been showing increasing interest in the Greek landscape, so far progress in related fields has been minimal and slow. Specifically, in the 1990s, landscape science in Greece underwent a shift from the fragmentary, peripheral and haphazard preoccupation of the design sciences with practical landscape issues as they developed out of physical interventions in urban space to a more concerted, focused and systematic landscape approach by several more disciplines and practitioners. This has, so far at least, remained mainly a qualitative shift characterized by its very limited extent and impact on actual landscape problems and issues in Greece, largely suffering from disciplinary limits and from the lack of communication and cooperation between academics, practitioners and administrators as well as from effective application in landscape policy. Clearly, what is required in the case of the Greek landscape is much further interdisciplinary engagement in landscape theory, methodology and development of techniques, as well as practical application and implementation of theoretical and research findings.

En dépit de l'intérêt croissant des scientifiques et des aménageurs pour le paysage grec, les progrès réalisés jusqu'ici dans des domaines relatifs à cette matière ont été minimes. Ainsi, au cours des années 1990, la science du paysage en Grèce a évolué, mais lentement. Initialement perçue comme une préoccupation fragmentaire, périphérique et peu méthodique des concepteurs pour les problèmes pratiques liés aux aménagements de l'espace urbain, cette science est passée à une approche plus concertée et plus systématique du paysage dans le chef de plusieurs autres disciplines ou de certains praticiens. Ce changement qualitatif est resté, jusqu'ici du moins, principalement caractérisé par une ampleur restreinte et par son impact extrêmement faible sur les problèmes posés par les paysages en Grèce, largement accentués par les limites des différentes disciplines et le manque de communication et de coopération entre l'université, le terrain et l'administration, ainsi que par la non-application des politiques en matière de paysages. De toute évidence, l'étude des paysages en Grèce souffre avant tout d'un défaut d'engagement interdisciplinaire sur la théorie, la méthodologie et le développement de 
techniques, mais aussi du manque d'application pratique et de mise en œuvre des résultats théoriques et des découvertes de la recherche.

INDEX

Mots-clés: Grèce, science du paysage, théorie du paysage, recherche sur les paysages, applications pratiques, interventions sur le paysage

Keywords: Greece, landscape science, landscape theory, landscape research, landscape applications, landscape interventions

\section{AUTHOR}

THEANO S. TERKENLI

Department of Geography, University of the Aegean, Lesvos, Greece, t.terkenli@aegean.gr 